\title{
Strength Properties of Foamed Concrete Containing Crushed Steel Slag as Partial Replacement of Sand with Specific Gradation
}

\author{
Hock Yong Tiong ${ }^{1 *}$, Siong Kang Lim $^{1}$, and Jee Hock Lim $^{1}$ \\ ${ }^{1}$ Lee Kong Chian Faculty of Engineering \& Science, Universiti Tunku Abdul Rahman, Bandar Sungai \\ Long, Cheras, 43000, Kajang, Selangor, Malaysia
}

\begin{abstract}
Lightweight construction material, notably foamed concrete, had become more favourable to reduce building weight and cost, accelerate construction process, and ease handling of precast segment. Simultaneously, rapid development had result in price rising of conventional material and environmental issue due to abundant wastes, for instance steel slag. As a consequence, feasibility of steel slag to be incorporated in lightweight foamed concrete for both structural and nonstructural purpose is worth to be investigated. This paper is aimed to evaluate the effects of crushed steel slag, as partial replacement of sand with specific gradation, on performance of lightweight foamed concrete (LFC) with density of $1600 \mathrm{~kg} / \mathrm{m}^{3}$ to $1700 \mathrm{~kg} / \mathrm{m}^{3}$ in terms of compressive and tensile strengths. Different steel slag based LFCs were developed by replacing $0,25,50,75$ and $100 \%$ of steel slag for sand. Different water to cement ratios $(\mathrm{w} / \mathrm{c})$ and dosages of super-plasticizer ( $\mathrm{sp}$ ) were adopted to confirm certain workability, strength properties was then studied for ages of 7 and 28 days. The laboratory results showed that lightweight foamed concrete with incorporation of crushed steel slag has decreased strength; however it still achieves structural strength of $17 \mathrm{MPa}$ when replacement level is less than $25 \%$ at density of $1600 \mathrm{~kg} / \mathrm{m}^{3}$ to $1700 \mathrm{~kg} / \mathrm{m}^{3}$.
\end{abstract}

\section{Introduction}

Lightweight foamed concrete (LFC), as one type of the lightweight concretes (LWC), is a mortar, in which artificial air voids are introduced by suitable foaming agent [1].

LWC possess a density between $300 \mathrm{~kg} / \mathrm{m}^{3}$ and $1850 \mathrm{~kg} / \mathrm{m}^{3}$ based on its type and usage, and can be classified by its purpose to structural lightweight concrete, concrete masonry unit, and insulating concrete [2]. According to ASTM C 330-89 [3], structural lightweight concrete should achieve 28-day cylinder compressive strength $\left(f_{\mathrm{ck}}\right)$ of $17 \mathrm{MPa}$, which approximately equivalent to characteristic cube strength $\left(f_{\mathrm{cu}}\right)$ of $21 \mathrm{MPa}$.

In the review study by Amran et al. [4], foamed concrete has found applied in many area such as structural application, lightweight blocks and pre-cast panel, shock absorbing barriers for traffic, road sub-base, cavity and void filling, repair and rehabilitation, fire,

* Corresponding author: tionghy3@gmail.com 
thermal, and acoustic insulation, and many other purposes $[1,5,6]$. Included in this review, annual market size of foamed concrete is estimated $250,000-300,000 \mathrm{~m}^{3}$ in the UK, $50,000 \mathrm{~m}^{3}$ in Western Canada, and 250,000 $\mathrm{m}^{3}$ just in floor heating system in Korea [7-9].

Steel slag is by-product of steel manufacturing. It has been noticed that per year fifty million tons of steel slag is generated from throughout the world $[10,11]$.

From the research carried out in the Asian country, approximately $10 \%$ of steel slag was produced from the production of steel, for instance, in Malaysia about 750 tons of steel were produced daily and approximately 7.5 tons of slag were produced [12].

However, the rate of utilization of steel slag in Malaysia is too low compared to some advanced countries. Albeit, steel slag is still used in some application such as asphalt aggregates for road construction, sub-base, cement stabilization, ground improvement and some other miscellaneous usage [12].

Maslehuddin et al. [13] fully replace coarse limestone aggregate ( $\mathrm{SG}=2.51)$ with coarse steel slag $(\mathrm{SG}=3.51)$ in normal concrete and report 5\% increment in compressive strength, reduction in absorption and permeability, but reduction in tensile strength.

Kothai and Malathy [14] partially replace fine sand $(\mathrm{SG}=2.65)$ with fine steel slag $(\mathrm{SG}=2.95)$ in normal concrete and found increment of compressive strength at $5 \%$ to $10 \%$ when replacement level is between $20 \%$ and $40 \%$, but have negligible increment on tensile strength; the gradation show that steel slag used has larger fineness modulus than that of sand.

Falade et al. [15] replace sand $(\mathrm{SG}=2.66)$ with steel slag $(\mathrm{SG}=3.47)$ in foamed concrete and found optimum replacement level of $30 \%$ with $20 \%$ increment in compressive strength, but the gradation are not specified.

Based on the above literature review, this study is aimed to study the effects of crushed steel slag on strength properties of lightweight foamed concrete (LFC) with density of 1600 $\mathrm{kg} / \mathrm{m}^{3}$ to $1700 \mathrm{~kg} / \mathrm{m}^{3}$ in terms of compressive and tensile strengths at ages of 7 and 28 days, where the gradation of steel slag is same as that of sand, and steel slag is replacing the sand at replacement level of $0 \%, 25 \%, 50 \%, 75 \%$ and $100 \%$.

\section{Experimental procedures}

In this study, strength properties of lightweight foamed concrete with super-plasticizer and crushed steel slag as partial of sand with specific gradation were evaluated.

\subsection{Materials}

Raw materials used for this study included cement, sand, steel slag, water, foam agent and super-plasticizer (sp).

The ordinary Portland cement complying with Type I Portland Cement in accordance with ASTM C 150-05 [16] was sieved through $300 \mu \mathrm{m}$ to remove all lumps, subsequently store in moisture-proof container indoor.

The natural river sand was oven-dried and sieved to ensure $100 \%$ passing rate for $2.36 \mathrm{~mm}$ opening. The steel slag, obtained from local hot-roll steel manufacturer, was washed, oven-dried, crushed, and sieved to have equivalent gradation with sand, as shown in Fig. 1. The sand has SG of 2.65 while steel slag has SG of 3.8. 


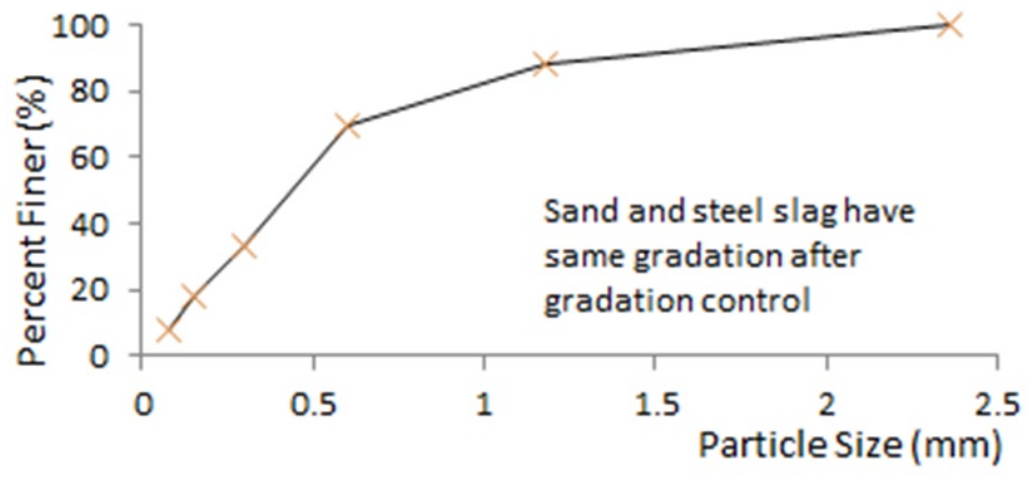

Fig. 1. Gradation of sand and steel slag.

The water used was tap water from the municipal water supply in accordance with ASTM 1602-06 [17]. Petroleum base synthetic detergent was used as foaming agent. Besides, the carboxylic ether type super-plasticizer was used in this study.

\subsection{Mix proportions}

The foamed concrete in this study was produced by using pre-foaming method, where base mix and pre-formed foam are produced separately and then mix together thoroughly $[1,18]$.

The foam used was dry foam that produced by forcing the foaming agent solution through a series of high density restrictions, and compressed air into mixing chamfer; it is very stable and has size of smaller than $1 \mathrm{~mm}[1,19]$. Foam agent and water was mixed in ratio of 1:30 in foam generator before applying compressed air.

The foamed concrete mix proportion and base mix density for different levels of steel slag replacement to sand is presented in Table 1.

Table 1. Mix proportion and details of foamed concrete.

\begin{tabular}{|c|c|c|c|c|c|c|}
\hline \multicolumn{2}{|c|}{ Replacement Level } & $0 \%$ & $25 \%$ & $50 \%$ & $75 \%$ & $100 \%$ \\
\hline \multicolumn{2}{|l|}{$\mathrm{w} / \mathrm{c}$} & 0.38 & 0.373 & 0.365 & 0.358 & 0.35 \\
\hline \multicolumn{2}{|l|}{ sp (\%) } & 1 & 0.875 & 0.75 & 0.625 & 0.5 \\
\hline \multirow{5}{*}{$\begin{array}{l}\text { material } \\
\text { per } \mathrm{m}^{3} \\
\text { foamed } \\
\text { concrete }\end{array}$} & cement $(\mathrm{kg})$ & 693 & 695 & 698 & 700 & 702 \\
\hline & sand $(\mathrm{kg})$ & 693 & 522 & 349 & 175 & 0 \\
\hline & steel slag $(\mathrm{kg})$ & 0 & 174 & 349 & 525 & 702 \\
\hline & water $(\mathrm{kg})$ & 261 & 257 & 253 & 249 & 245 \\
\hline & $\mathrm{sp}(\mathrm{L})$ & 2.63 & 2.27 & 1.91 & 1.56 & 1.23 \\
\hline \multicolumn{2}{|c|}{ base mix density $\left(\mathrm{kg} / \mathrm{m}^{3}\right)$} & 2215 & 2285 & 2360 & 2440 & 2525 \\
\hline \multirow{2}{*}{$\begin{array}{l}\text { foam } \\
\text { required }\end{array}$} & volume $\left(\mathrm{m}^{3}\right)$ & 0.255 & 0.278 & 0.300 & 0.323 & 0.347 \\
\hline & mass $(\mathrm{kg})$ & 11.47 & 12.49 & 13.52 & 14.55 & 15.60 \\
\hline
\end{tabular}

The foam volume required is affected by base mix density and target density. In this study, dosage of super-plasticizer and water to cement ratio were varied to obtain equivalent level of base mix flowability based on observation. Base mix density is mainly affected by replacement level of steel slag due to large difference between specific gravity of steel slag and that of sand. The water to cement ratio has very minor effect on base mix 
density, for instance, when the water to cement ratio for $0 \%$ replacement was change to 0.35 , the base mix density, instead of $2215 \mathrm{~kg} / \mathrm{m}^{3}$, will be $2250 \mathrm{~kg} / \mathrm{m}^{3}$ compare to 2525 $\mathrm{kg} / \mathrm{m}^{3}$ at $100 \%$ replacement level.

\subsection{Testing methods}

Testing method used for this study include inverted slump test, compression, split tensile, and flexural tests.

Inverted slump test was performed as per ASTM C 1611-05 [20] to determine the workability of foamed concrete. The slump cone, as per ASTM C 143-08 [21], was placed on a centre of flat base plate with the smaller opening facing down, and filled with foamed concrete. Immediately, the cone was lifted up vertically with a distance of $225 \pm 75 \mathrm{~mm}$ in $3 \pm 1$ seconds. The average spread diameter was measured after the concrete stop flowing.

Compressive test was conducted as per BS EN 12390-3 [22]. The concrete cubical specimens with dimension of $100 \mathrm{~mm}$ were tested by using a universal compression machine with loading rate of $3 \mathrm{kN} / \mathrm{s}$.

Split tensile test was conducted as per BS EN 12390-6 [23]. The cylindrical specimens with $100 \mathrm{~mm}$ diameter and $200 \mathrm{~mm}$ length were place horizontally with packing strip and tested by universal compression test machine with loading rate of $1.76 \mathrm{kN} / \mathrm{s}$.

Flexural test was performed using centre-point loading method as per BS EN 12390-5 [24]. The specimens with $40 \mathrm{~mm} \times 40 \mathrm{~mm}$ cross section and total length of $160 \mathrm{~mm}$ were tested by using testing machine named INSTRON 5582 with effective length of $120 \mathrm{~mm}$ and loading rate of $0.008 \mathrm{~mm} / \mathrm{min}$.

\section{Results and discussion}

\subsection{Workability}

Inverted slump test results were shown in Table 2. It was noticed that increment of foam volume has reduced the inverted slump flow of foamed concrete, as shown in Table 2.

Table 2. Workability of foamed concrete.

\begin{tabular}{|l|l|l|l|l|l|}
\hline Replacement Level & $0 \%$ & $25 \%$ & $50 \%$ & $75 \%$ & $100 \%$ \\
\hline Inverted Slump value (mm) & 655 & 680 & 675 & 645 & 555 \\
\hline
\end{tabular}

\subsection{Compressive strength}

Hardened density, percentage of foam, compressive strength and corresponding compressive strength were tested and evaluated in Table 3.

The relationship between compressive strength and percentage of foam volume, regardless the effect of steel slag, was shown in Fig. 2. Base on the relationship, the corresponding strength at any density between $1600 \mathrm{~kg} / \mathrm{m}^{3}$ to $1700 \mathrm{~kg} / \mathrm{m}^{3}$ can be calculated. Hence, the corresponding compressive strength at density of $1700 \mathrm{~kg} / \mathrm{m}^{3}$ was calculated and shown in Table 3.

The compressive strength, performance index of compressive strength, and corresponding compressive strength were compared, as shown in Fig. 3. Performance index is strength per $1000 \mathrm{~kg} / \mathrm{m}^{3}$ density, calculated by strength divided by the density, was used to evaluate the strength performance. 
It was noticeable that compressive strength and performance index were influenced by the achieved hardened density, whereas corresponding compressive strength shows an approximate linear transforms, in which, compressive strength was reduced when steel slag replacement level was increased.

The previous researches which indicate increment of strength might have different gradation for sand and steel slag, where steel slag might have larger fineness modulus [14], and have smaller specific gravity [13-15].

No doubt certain amount of fine steel slag is able to improve the strength of concrete $[14,15]$, but it was insufficient to compensate the reduction of strength cause by increment of foam volume due to high specific gravity of steel slag used.

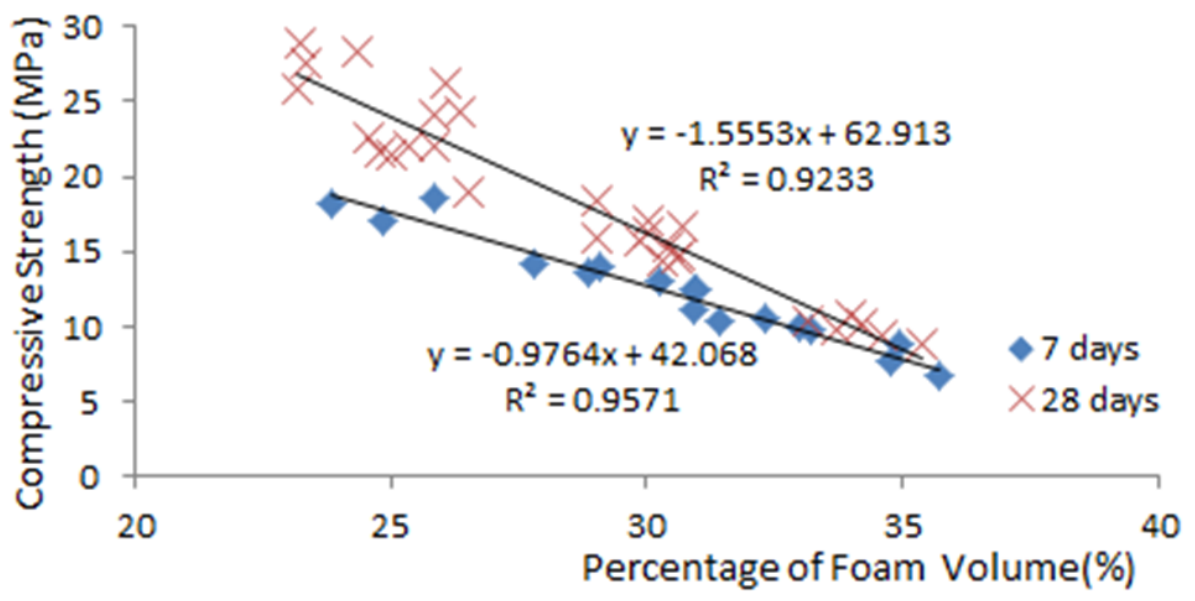

Fig. 2. Relationship between compressive strength and foam volume.

Table 3. Compressive strength, hardened density, and percentage of foam volume

\begin{tabular}{|l|l|l|l|l|l|l|}
\hline \multicolumn{2}{|l|}{ Replacement level } & $0 \%$ & $25 \%$ & $50 \%$ & $75 \%$ & $100 \%$ \\
\hline Percentage of Foam in Volume at $1700 \mathrm{~kg} / \mathrm{m}^{3}$ & 23.2 & 25.6 & 27.9 & 30.3 & 32.7 \\
\hline \multirow{4}{*}{7 days } & Hardened Density $\left(\mathrm{kg} / \mathrm{m}^{3}\right)$ & 1647 & 1622 & 1634 & 1654 & 1637 \\
\cline { 2 - 7 } & Percentage of Foam Volume (\%) & 25.6 & 29.0 & 30.7 & 32.2 & 35.2 \\
\cline { 2 - 7 } & Compressive Strength (MPa) & 17.0 & 13.8 & 12.6 & 10.4 & 7.7 \\
\cline { 2 - 7 } & $\begin{array}{l}\text { Corresponding Compressive Strength at } \\
1700 \mathrm{~kg} / \mathrm{m}^{3}(\mathrm{MPa})\end{array}$ & 19.3 & 17.2 & 15.4 & 12.6 & 9.6 \\
\hline \multirow{4}{*}{28 days } & Hardened Density $\left(\mathrm{kg} / \mathrm{m}^{3}\right)$ & 1677 & 1676 & 1647 & 1630 & 1660 \\
\cline { 2 - 7 } & Percentage of Foam Volume (\%) & 24.3 & 26.6 & 30.2 & 33.2 & 34.3 \\
\cline { 2 - 7 } & Compressive Strength (MPa) & 24.8 & 21.9 & 16.1 & 10.8 & 10.1 \\
\cline { 2 - 7 } & $\begin{array}{l}\text { Corresponding Compressive Strength at } \\
1700 \mathrm{~kg} / \mathrm{m}^{3}(\mathrm{MPa})\end{array}$ & 26.4 & 23.6 & 19.6 & 15.3 & 12.4 \\
\hline 7 days / 28 days Corresponding Strength & $73 \%$ & $73 \%$ & $79 \%$ & $82 \%$ & $77 \%$ \\
\hline
\end{tabular}




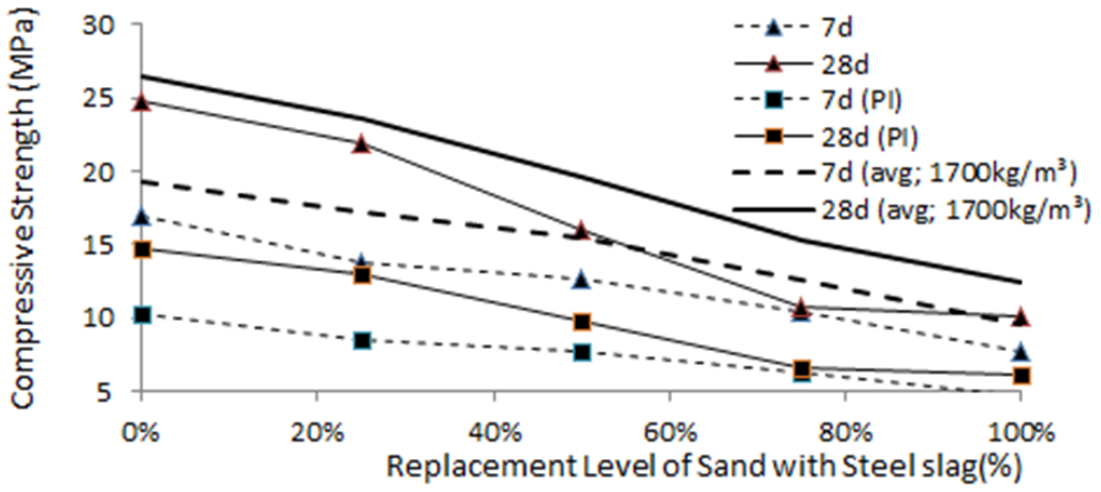

Fig. 3. Comparison between compressive strength, performance index (PI) of compressive strength, corresponding compressive strength and replacement level of steel slag.

\subsection{Split tensile strength}

Hardened density, percentage of foam, split tensile strength and corresponding split tensile strength were tested and evaluated in Table 4.

The relationship between split tensile strength and percentage of foam volume, was shown in Fig. 4, and the corresponding split tensile strength was calculated based on the relationship and shown in Table 4.

The split tensile strength, performance index of split tensile strength, and corresponding split tensile strength were compared in Fig. 5. It was also noticeable that split tensile strength and performance index were influenced by the achieved hardened density. Therefore, corresponding split tensile strength was estimated for comparison and concluded that, similar to compressive strength, split tensile strength was reduced almost linearly when steel slag replacement level was increased.

Split tensile strength is found at $8 \%$ to $10 \%$ corresponded to compressive strength in this study. Byun et al. had found a similar result $[4,18]$.

Table 4. Split tensile strength, hardened density, and percentage of foam in volume

\begin{tabular}{|l|l|l|l|l|l|l|}
\hline \multicolumn{2}{|l|}{ Replacement level } & $0 \%$ & $25 \%$ & $50 \%$ & $75 \%$ & $100 \%$ \\
\hline Percentage of Foam in Volume at $1700 \mathrm{~kg} / \mathrm{m}^{3}$ & 23.2 & 25.6 & 27.9 & 30.3 & 32.7 \\
\hline \multirow{4}{*}{7 days } & Hardened Density $\left(\mathrm{kg} / \mathrm{m}^{3}\right)$ & 1629 & 1655 & 1628 & 1635 & 1648 \\
\cline { 2 - 7 } & Percentage of Foam Volume (\%) & 26.4 & 27.5 & 31.0 & 33.0 & 34.7 \\
\cline { 2 - 7 } & Split Tensile Strength (MPa) & 1.6 & 1.43 & 1.04 & 0.91 & 0.74 \\
\cline { 2 - 7 } & $\begin{array}{l}\text { Corresponding Split Tensile Strength at } \\
1700 \mathrm{~kg} / \mathrm{m}^{3}(\mathrm{MPa})\end{array}$ & 1.90 & 1.62 & 1.35 & 1.17 & 0.94 \\
\hline \multirow{4}{*}{28 days } & Hardened Density (kg/m $\left.\mathrm{m}^{3}\right)$ & 1659 & 1637 & 1644 & 1647 & 1631 \\
\cline { 2 - 7 } & Percentage of Foam Volume (\%) & 25.1 & 28.3 & 30.3 & 32.5 & 35.4 \\
\cline { 2 - 7 } & Split Tensile Strength (MPa) & 2.00 & 1.61 & 1.44 & 1.14 & 0.79 \\
\cline { 2 - 7 } & $\begin{array}{l}\text { Corresponding Split Tensile Strength at } \\
1700 \mathrm{~kg} / \mathrm{m}^{3} \text { (MPa) }\end{array}$ & 2.21 & 1.93 & 1.72 & 1.39 & 1.11 \\
\hline 7 days / 28 days Corresponding Strength & $86 \%$ & $84 \%$ & $78 \%$ & $84 \%$ & $85 \%$ \\
\hline
\end{tabular}




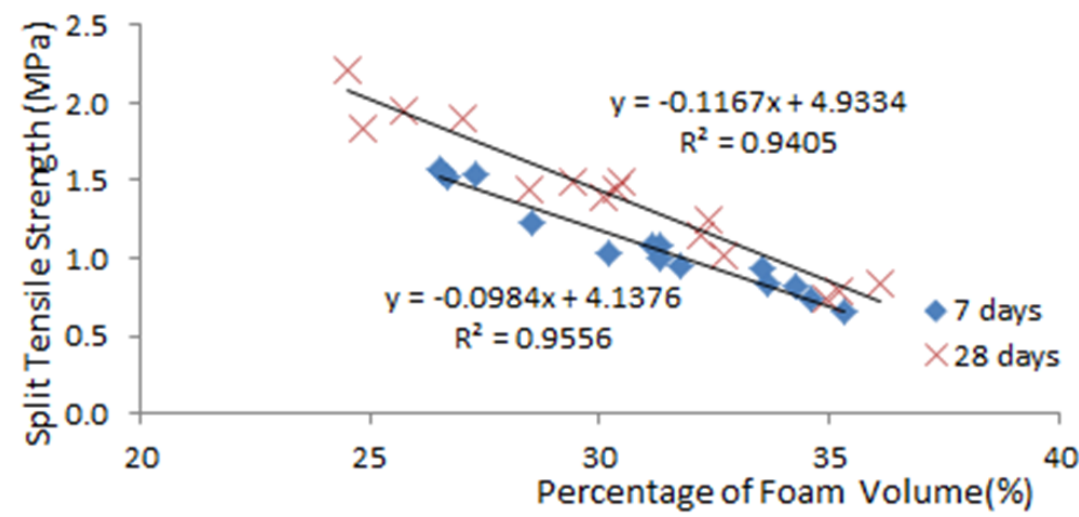

Fig. 4. Relationship between split tensile strength and foam volume.

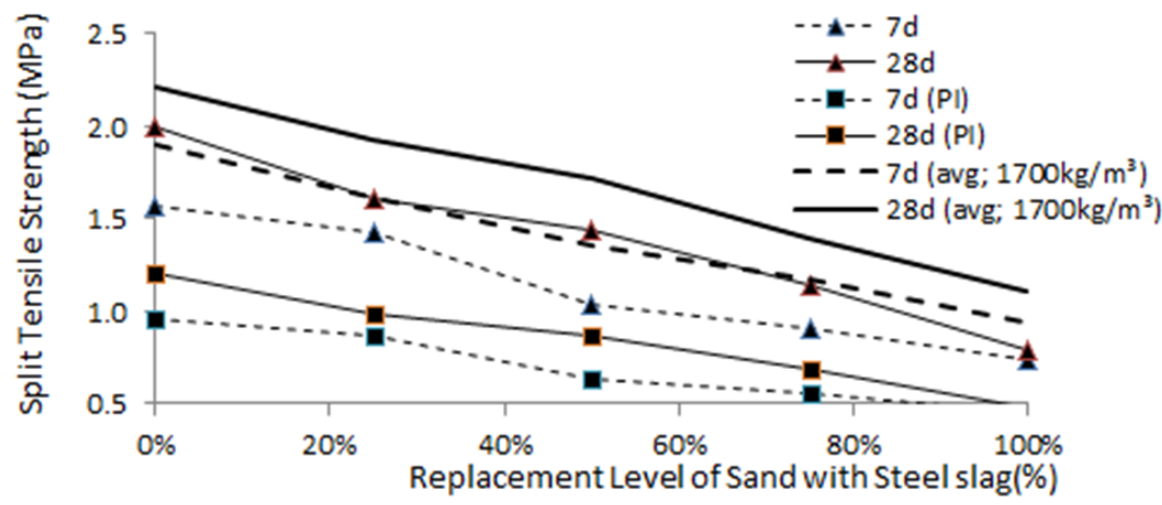

Fig. 5. Comparison between split tensile strength, performance index (PI) of split tensile strength, corresponding split tensile strength and replacement of steel slag

\subsection{Flexural strength}

Hardened density, flexural strength and performance index of flexural strength were tested and evaluated in Table 5.

The flexural strength and performance index of flexural strength were compared in Fig. 6. Approximate linear reduction of flexural strength performance index by increment of steel slag replacement was observed.

Table 5. Flexural strength, hardened density, and performance index of flexural strength

\begin{tabular}{|l|l|l|l|l|l|l|}
\hline \multicolumn{2}{|l|}{ Replacement level } & $0 \%$ & $25 \%$ & $50 \%$ & $75 \%$ & $100 \%$ \\
\hline \multirow{3}{*}{7 days } & Hardened Density $\left(\mathrm{kg} / \mathrm{m}^{3}\right)$ & 1628 & 1616 & 1615 & 1647 & 1616 \\
\cline { 2 - 7 } & Flexural Strength $(\mathrm{MPa})$ & 7.40 & 6.15 & 4.44 & 3.53 & 3.17 \\
\cline { 2 - 7 } & Performance Index $\left(\mathrm{PI}, \mathrm{MPa} / 1000 \mathrm{~kg} / \mathrm{m}^{3}\right)$ & 4.51 & 3.81 & 2.75 & 2.14 & 1.96 \\
\hline \multirow{3}{*}{28 days } & Hardened Density $\left(\mathrm{kg} / \mathrm{m}^{3}\right)$ & 1632 & 1621 & 1624 & 1595 & 1625 \\
\cline { 2 - 7 } & Flexural Strength $(\mathrm{MPa})$ & 7.80 & 7.23 & 5.95 & 5.07 & 4.04 \\
\cline { 2 - 7 } & Performance Index $\left(\mathrm{PI}, \mathrm{MPa} / 1000 \mathrm{~kg} / \mathrm{m}^{3}\right)$ & 4.78 & 4.46 & 3.66 & 3.18 & 2.49 \\
\hline 7 days / 28 days Strength & $94 \%$ & $85 \%$ & $75 \%$ & $70 \%$ & $78 \%$ \\
\hline
\end{tabular}




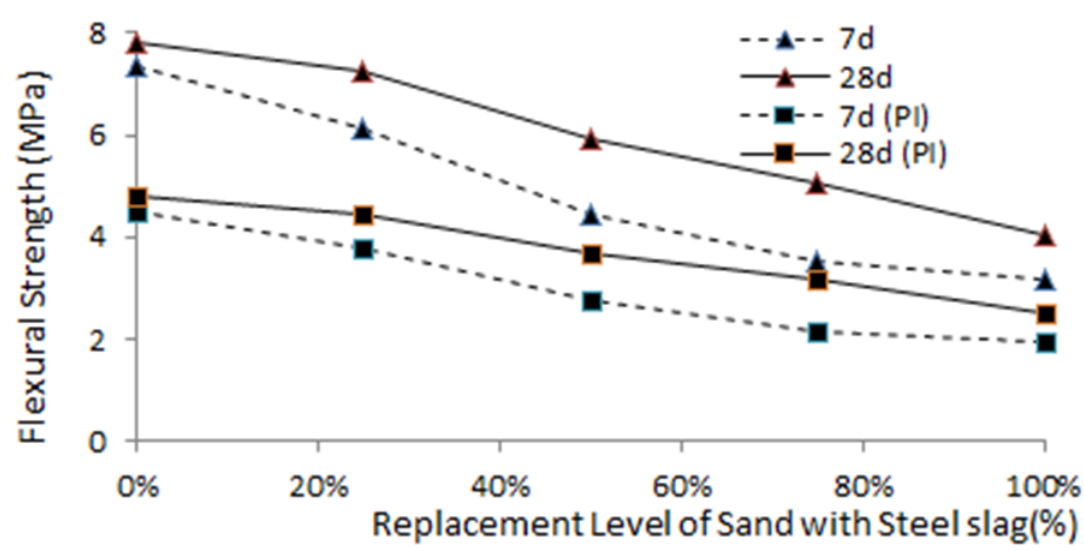

Fig. 6. Comparison between flexural strength, performance index (PI) of flexural strength, and replacement level of steel slag.

Performance index of flexural strength is found at $32 \%$ to $48 \%$ corresponded to its performance index of compressive strength in this study, which is very different from split tensile strength. Byun et al. also found similar result, which is, flexural strength is $20 \%$ to $40 \%$ of compressive strength, whereas split tensile strength is $8 \%$ to $11 \%$ of compressive strength $[4,18]$.

\section{Conclusions}

Strength properties of foamed concrete with density of $1600 \mathrm{~kg} / \mathrm{m}^{3}$ to $1700 \mathrm{~kg} / \mathrm{m}^{3}$ was studies, in which sand with specific gravity of 2.65 was partially replaced by steel slag with specific gravity of 3.8 and similar gradation, with different replacement level, namely $0 \%$, $25 \%, 50 \%, 75 \%$, and $100 \%$.

The results show that the compressive, split tensile and flexural strengths were reduced almost linearly with increment of replacement level, however, with replacement level of $25 \%$ and lesser at density of $1600 \mathrm{~kg} / \mathrm{m}^{3}$ to $1700 \mathrm{~kg} / \mathrm{m}^{3}$, the achieved 28 days strength fulfil the structural strength of $17 \mathrm{MPa}$ set by ASTM C 330-89 [3].

The split tensile strength is found $8 \%$ to $10 \%$ of compressive strength, whereas flexural strength is found $32 \%$ to $48 \%$ of compressive strength.

The support provided by Universiti Tunku Abdul Rahman (UTAR) in the form of a research grant (Vote No. 6200/LG3), and Masteel BhD in the form of raw steel slag for this study is very much appreciated.

\section{References}

[1] K. Ramamurthy, E. Kunhanandan Nambiar, and G. Indu Siva Ranjani, A classification of studies on properties of foam concrete, Cement and Concrete Composites, 31 (6), 388-396, (2009)

[2] A. Neville and J. Brooks, Concrete technology. Harlow, Essex, UK: Longman Scientific \& Technical, 346, 350-351, (1987)

[3] ASTM C 330-89, Standard Specification for Lightweight Aggregates for Structural Concrete, ASTM International, Conshohocken, Pennsylvania, United States, (1989) 
[4] Y. Amran, N. Farzadnia and A. Abang Ali, Properties and applications of foamed concrete; a review, Construction and Building Materials, 101, 990-1005, (2015)

[5] N. Uddin, Structural characterization of hybrid fiber reinforced polymer (FRP)autoclave aerated concrete (AAC) panels, J. of Reinforced Plastics and Composites, 25 (9), 981-999, (2006)

[6] A. Just, and B. Middendorf, Microstructure of high-strength foam concrete, Materials Characterization, 60 (7), 741-748, (2009)

[7] M.R. Jones, and A. McCarthy, Behaviour and Assessment of Foamed Concrete for Construction Applications, Thomas Telford, London, UK (2005)

[8] M. Rößler, and I. Odler, Investigations on the relationship between porosity, structure and strength of hydrated Portland cement pastes I. Effect of porosity, Cement and Concrete Research, 15 (2), 320-330 (1985)

[9] K. Yang, K. Lee, J. Song, and M. Gong, Properties and sustainability of alkali-activated slag foamed concrete, J. of Cleaner Production, 68, 226-233, (2014)

[10] M. Hainin, M.A. Aziz, Z. Ali, R. Putra Jaya, M. El-Sergany, and H. Yaacob, Steel slag as a road construction material, J. Technolology, 73 (4) (2015)

[11] H. Motz, and J. Geiseler, Products of steel slags an opportunity to save natural resources, Waste Management, 21(3), 285-293, (2001)

[12] E. Oluwasola, M. Hainin and M. A. Aziz, Characteristics and utilization of steel slag in road construction, J. Technology, 70 (7), (2014)

[13] M. Maslehuddin, A. Sharif, M. Shameem, M. Ibrahim, and M. Barry, Comparison of properties of steel slag and crushed limestone aggregate concretes, Construction and Building Materials, 17 (2), 105-112, (2003)

[14] P. Kothai, and R. Malathy, Utilization of steel slag in concrete as a partial replacement material for fine aggregates, IJIRSET Int. J. of Innovative Research In Science, Engineering and Technology, 3 (4), (2014)

[15] F. Falade, E. Ikponmwosa, and B. Ukponu, Structural assessment of foamed concrete containing steel slag as partial replacement of sand, UNILAG J. of Medicine, Science and Technology, 1 (1), 137-145, (2015)

[16] ASTM C 150-05, Standard Specification for Portland Cement, ASTM International, Conshohocken, Pennsylvania, United States, (2005)

[17] ASTM C1602-06, Standard Specification for Mixing Water Used in the Production of Hydraulic Cement Concrete, ASTM International, Conshohocken, Pennsylvania, United States, (2006)

[18] K. Byun, H. Song, and S. Park, Development of structural lightweight foamed concrete using polymer foam agent, Int. Congress on Polymers in Concrete, 19, (1998)

[19] D. Aldridge, and T. Ansell, Foamed concrete: production and equipment design, properties, applications and potential. In: Proc. of one day seminar on foamed concrete: properties, applications and latest technological developments, Loughborough University, Loughborough, UK, (2001)

[20] ASTM C 1611-05, Standard Test Method for Slump Flow of Self-Consolidating Concrete, ASTM International, Conshohocken, Pennsylvania, United States, (2005)

[21] ASTM C 143-08, Standard Test Method for Slump of Hydraulic-Cement Concrete, ASTM International, Conshohocken, Pennsylvania, United States, (2008)

[22] BS EN 12390-3, Testing Hardened Concrete: Compressive Strength of Test Specimens, British Standard Institution, London, UK, (2002)

[23] BS EN 12390-6, Testing Hardened Concrete: Tensile Splitting Strength of Test Specimens, British Standard Institution, London, UK, (2000)

[24] BS EN 12390-5, Testing Hardened Concrete: Flexural Strength of Test Specimens, British Standard Institution, London, UK, (2000) 